\title{
Efficient maltotriose fermentation through hydrolysis mediated by the intracellular invertase of Saccharomyces cerevisiae
}

\author{
Victor Ribeiro de Godoy ${ }^{*}$, Gabriela Muller, Bóris Stambuk \\ From 5th Congress of the Brazilian Biotechnology Society (SBBIOTEC) \\ Florianópolis, Brazil. 10-14 November 2013
}

\begin{abstract}
Background
It is well known that in the yeast $S$. cerevisiae the sugars sucrose and maltose/maltotriose are metabolized by different pathways: sucrose is hydrolyzed by extracellular invertase (encoded by SUC genes), while maltose and maltotriose are actively transported into the cell and hydrolyzed by intracellular $\alpha$-glucosidases (both proteins encoded by the $M A L$ genes). Nevertheless, several reports have shown that some SUC genes can be located proximal to $M A L$ genes at the telomeres of different chromosomes. Furthermore, the SUC genes also allow the synthesis of an intracellular form of invertase, an enzyme with no obvious function in yeasts [1]. We have already shown that sucrose can be metabolized by yeast cells through $M A L$-encoded transporters and $\alpha$-glucosidases.
\end{abstract}

\section{Methods, results and conclusions}

Now, our results will show that maltotriose can be efficiently fermented by $S$. cerevisiae cells through its active transport mediated by the $A G T 1$ permease, a $M A L$ transporter required for maltotriose utilization $[2,3]$, and its intracellular hydrolysis mediated by the cytoplasmic invertase. The Brazilian industrial fuel-ethanol strain CAT-1 cannot ferment maltotriose efficiently due to a defective promoter of the AGT1 gene [4]. To increase maltotriose fermentation by this strain, we placed a strong promoter $\left(\mathrm{P}_{\mathrm{GPD}}\right)$ in the AGT1 gene of strain CAT-1, generating strain GMY05. While the AGT1 gene was indeed overexpressed in this strain (measured by real-time PCR and a specific transport assay), maltotriose was still not fermented efficiently. However, when we over-expressed the intracellular form of invertase, by replacing the signal sequence of the SUC2 gene with the strong $\mathrm{P}_{\mathrm{PGK}}$ promoter, the

Universidade Federal de Santa Catarina, Florianópolis, SC, Brazil resulting iSUC2 strain GMY08 fermented maltotriose efficiently. Using conditions were the $M A L$-encoded $\alpha$-glucosidases would not be expressed, we could show that the intracellular form of invertase hydrolyzes maltotriose efficiently (but not maltose or $p$-nitrophenyl- $\alpha$-glucoside), specially at the cytoplasmic $\mathrm{pH}$ of 7.0. Under the same conditions we purified the intracellular invertase by ion-exchange chromatography, and the identity of the enzyme confirmed by mass spectrophotometry. With the purified enzyme we performed enzymatic tests that corroborated our previous analysis, showing that intracellular invertase hydrolyzes maltotriose. Thus, our results indicate an unexpected overlap in sucrose-maltotriose metabolism by yeast cells, showing that the intracellular invertase allows efficient maltotriose hydrolysis, and offers new approaches that can be applied to optimize several industrial fermentation processes that use starch hydrolysates, including production of distilled beverages, brewing and backing.

\section{Acknowledgements}

This work was funded by the Brazilian agencies CAPES, CNPq, and FINEP.

\section{Published: 1 October 2014}

\section{References}

1. Basso TO, De Kok S, Dario M, Do Espirito-Santo JCA, Muller G, Schlolg PS, Silva CP, Tonso A, Daran JM, Gombert AK, Van Maris AJA, Pronk JT, Stambuk BU: Engineering topology and kinetics of sucrose metabolism in Saccharomyces cerevisiae for improved ethanol yield. Metab Eng 2011, 13:694-703.

2. Alves SL JR, Herberts RA, Hollatz C, Trichez D, Miletti LC, De Araujo PD, Stambuk BU: Molecular analysis of maltotriose active transport and fermentation by Saccharomyces cerevisiae reveals a determinant role for the AGT1 permease. Appl Environ Microbiol 2008, 74:1494-1450.

3. Duval EH, Alves SL JR, Dunn B, Sherlock GJ, Stambuk BU: Microarray karyotyping of maltose fermenting Saccharomyces yeasts with differing maltotriose utilization profiles reveals copy number variation in genes involved in maltose and maltotriose utilization. Journal of Applied Microbiology 2010, 109:248-259. 
4. Babrzadeh F, Jalili R, Wang C, Shokralla S, Pierce S, Robinson-Mosher A, Nyren P, Shafer RW, Basso LC, De Amorim HV, De Oliveira AJ, David RW, Ronagui M, Gharizadeh B, Stambuk BU: Whole-genome sequencing of the efficient industrial fuel-ethanol fermentative Saccharomyces cerevisiae strain CAT-1. Mol Genet Genomics 2012, 287:485-494.

doi:10.1186/1753-6561-8-S4-P181

Cite this article as: de Godoy et al:: Efficient maltotriose fermentation

through hydrolysis mediated by the intracellular invertase of

Saccharomyces cerevisiae. BMC Proceedings 2014 8(Suppl 4):P181.

Submit your next manuscript to BioMed Central and take full advantage of:

- Convenient online submission

- Thorough peer review

- No space constraints or color figure charges

- Immediate publication on acceptance

- Inclusion in PubMed, CAS, Scopus and Google Scholar

- Research which is freely available for redistribution

Submit your manuscript at www.biomedcentral.com/submit
Ciomed Central 